\title{
COVID-19, REMITTANCE INFLOW, AND ECONOMIC GROWTH RATE IN NEPAL
}

\author{
Arbind Chaudhary* \\ * Mr. Chaudhary is currently working, as a research officer,at Research Centre for \\ Development Studies (RCDS), Lalitpur, Nepal.Email: acsir21@gmail.com
}

\begin{abstract}
The proliferation of COVID-19 pandemic over the globe is anomalously hurting the world's economy. The paper aims to reveal the possible loss in economic growth rate for FY 2020 due to plausible retardation in remittance/GDP size of Nepal under COVID- 19 regime by utilizing transmission approach, trend forecast, and ordinary least square method form 2000 to 2019. The study harvests two premises: first, remittance/GDP has a positive estimate to the economic growth rate and second, if the pandemic proliferates more, and if it downsizes the remittance/ GDP size by $25 \%$ to $75 \%$, it reduces the projected GDP growth rate (6.95) up to 6.68 to $5.3 \%$ respectively for FY 2020. However, domestic literature also supports the strong role of remittance on the micro-level. Therefore, the microeconomic impact of the virus may be more appalling than the macro-economic ground.
\end{abstract}

Keywords: COVID-19 - remittance - transmission approach - OLS, RMSE economic growth.

\section{HISTORICAL BACKGROUND OF COVID-19}

On 30 January 2020, the World Health Organization declared a novel coronavirus 'COVID-19' a matter of public health emergency of international concern.In February of 2020, with the first death from COVID-19 in France and a steep increase of positive cases in Italy, the coronavirus pandemic became a matter of significant concern in Europe (Klonowska, 2020). COVID-19 is spreading fast across the globe. On 11 July 2020, the World Health Organization(2020) reports that 13,036,550 are the total cases, and 571,574 are total death cases up to now. Among the world, the USA has recorded top rank in both total death cases and total infected cases by 137,782 and 3,413,995 respectively, and Brazil is in the second rank. The illustrative scenarios indicate that the potential 
loss of income in affected countries could be significant, with global GDP declining by up to $3.9 \%$, and developing countries hit the hardest ( $4 \%$ on average, but some over 6.5\%).Furthermore,governments will need to offer significant support to affected businesses and households (Maliszewska et al., 2020). As of 25 March 2020, the John Hopkins Corona dashboard indicated 466,000 confirmed cases of COVID- 19, affecting 196 countries and territories. The virus has a higher transmission rate than either the 2003 SARS or the 2008 MEV outbreaks. Mortality rates have doubled nearly every three days in cases like Spain, the United Kingdom, and the United States (Klimburg et al., 2020).

To defeat the spread of COVID-19, many countries partially or fully have been closing their borders and restricting the movement of people. The PRC was first to enforce restrictions, placing Wuhan 11 million population - under lockdown, and restricting movement across Hubei Province, where 57 million population are living. Similarly, Italy started to quarantine the "red zone"in 11 towns and villages in the Lombardy and Veneto regions. Later, it was extended across the entire country (60 million population). In the same way, the USA imposed travel bans decision. As of 28 March 2020, over 156 countries regulated the travel restriction denying entry, restricting visas, or imposing mandatory quarantine and 104 countries were closed entirely (IATA, 2020). Furthermore, the Asian Development Bank (2020a) emphasizes a few control measures restrictions to transport, labor mobility, and workplace closures acted as supply shocks to the economy. Initially, restrictions on transport and the movement of labor hurt the economy's production capacity, disrupting entire supplies. This dripped the aggregate demand as people were locked down in their homes and workers were laid off and lost income. Air travel restrictions and border closures limited both the movement of people and the movement of commodities across borders.

Initialy, ILO (2020) estimates a significant rise in unemployment and underemployment in the wake of the virus. Based on different scenarios for the impact of COVID-19 on global GDP growth, preliminary it estimates a rise in global unemployment, about 5.3 milliona "low" scenario, and 24.7 million a "high" scenario. In the same token, the "mid" scenario suggests an increase of 13 million (among 7.4 million in high-income countries). Therefore, all figures indicate a substantial rise in global unemployment like 
the global financial crisis of 2008-9, where unemployment was ballooned by 22 million.

\section{REMITTANCE IN NEPAL}

In international economics, factors of production are dynamic and the process is calledinternational factor movements (IFMs). In this regard, the labor movement is known as immigration or emigration (Krugman et al., 2012). Similarly,IMF (2009)outlinesremittance is the household income from foreigncountries due tothe temporary or permanent movement of people.It may be in the form of cash andnon-cash items that flows through legalchannels, i.e.electronic wire, or through informal channels, i.e. money or goods carried across borders. The remittance-as a source of development funding - is directly linked to international migration. Unconditionally, remittance provides a significant disposable income (acting as a substitute for earned income) against massive unemployment, illness, retirement, emigration, falling wages, and crop failure. Ultimately it protects poor families.

Nepal, 19 $9^{\text {th }}$ top remittance achiever in 2018, is popular for exporting thelabor because of various reasons, for instance, civil war, political persecution, or economic hardships. Where,Indiais reportedas the world's top recipient of remittances followed by China ( $\$ 67.41$ billion) (Sophie, 2019).Dhunagana (2014) observes that most of the remittance in Nepal is going into consumption, which leads to the dearth of resources for investment. Furthermore, CBS (2011) reflects that 78.9 percent of total remittance is spent in daily consumption, whereas 7.1 percent inrepayment of loans, 4.5 percent in household property, 3.5 percent in education, and 2.4 percent in capital formation. Thus, the remittance is unable to fulfill the widened resource gap of the domestic economy. It is one of the serious issues for the improvement of the investment scenario in Nepal to encourage more capital formation.Hence, these facts are now badly affected by COVID -19. It may hurt the various aspects (micro-and macro) of the economy. At this moment, where millions of people have been suffering health issues, simultaneously most of the economies are facing different kinds of hindrances.

Nepal, popularly known as a good remittance recipient country, is also facing similar problems like the world. Specifically, the pandemic badly attacks to the international labor market for Nepalese workers. Thus, 
it is clear that COVID-19 is going to deteriorate the remittance inflow and other harms to the Nepalese economy. It is not sure how much it will retard the remittance inflow from overseas. It's all depends on the probability or intensity of the virus. Therefore, The paper aims to reveal the possible loss in economic growth rate due to possible retardation in remittance inflow (\% of GDP) under the coronavirus regime. Whenever, most of the economies are estimating the possible economic, human, and social losses during this pandemic period; this study also significant for estimating the possible loss in remittance/GDP share and its effect on the economic growth rate for FY 2020. It also provides a suitable policy for soothing the current economic problem.

\section{LITERATURE SURVEY}

The most of literature regarding COVID-19, for instance, Maliszewska et al., (2020), Klimburg et al.(2020), Asian Development Bank (2020b), ILO(2020),etc., are important for this paper. However,a significant portion of relevant domestic literature on remittance argues that they are primarily spent on consumption, housing, land, and are not significantly utilized for productive investment that would contribute tothe long-run development of the Nepalese economy. The recognition that only a small proportion of remittances are employed to establish small- scale businesses, improve agricultural, and other forms of productive investment. Remittancecan generate a positive effect on the economy through various channels, for instance, savings, investment, consumption, and income distribution. These inflows can also contribute to stability by lowering the probability of current account problems. Johan et al.(2015) explore the positive effect of remittance on economic growth in the West Africa region. Calaro (2008) reveals that remittances reduce the poverty, loan of the households, andaccelerating investment, human development,education, and health.Katsushi et al. (2012), in their work remittance growth and poverty, new evidence fromthe Asian countries generally confirm that remittance has a positive impact on economic growth, the work also found a positive impact of remittance on poverty alleviation. Javid, Arif, and Qayyum (2012) find the significant and positive role of remittance on economic growth and poverty reduction in Pakistan.Similarly, on the contrary,Chami et al (2003) identify the negative attitude effect of remittances that adversely affect economic growth. According to the recipient who is guaranteed funds from abroad are not motivated to work and may reduce their work effort while keeping the same level of income which inimical to growth. 
Gaudel (2006) explores that remittance and labor migration support their family at the micro-level and it induces other young labor forces to go abroad. Srivastava and Chaudhary (2007) explore the positive impact on the per capita income in Nepal. Shrestha (2008) concludes that remittances sent by migrant workers are an effective tool for poverty reduction. Pant (2011) explores the harnessing remittance for productive use in Nepal. He concludes that remittance contributes largely to the national economy. The remittance inflow significantly reduces poverty, improves the standard of living and educational level. Similarly, Gautam (2017) identifies that remittance induces household purchasing power, and the remittance recipient households expending better on basic goods, for example, food, shelter, education, etc., in Nepal than the non-remittance recipient household. Bhandari (2018) adds remittance significantly empower the Nepali women in business entrepreneurship in small and cottage-based industries in Nepal.

\section{DATA AND METHODOLOGY}

The study follows the descriptive and experimental research framework to solve the raised issue under the mixed type of methods. The first step is the trend forecast under the Root Mean Square Error (RMSE) technique. RMSE, a good measure of how accurately the model predicts the response, is the most important criterion for fit if the main purpose of the model is prediction. The lower value of RMSE indicatesa better fit. (Chai, 2014). Second is the ordinary least square computation. The process of the forecast is divided into two parts. First, it forecasts the share of remittance in GDP and GDP growth rate for 2020 assuming the absence of the pandemic. Then, assumes a possible range of loss in remittance/ GDP due to coronavirus, i.e., $25 \%, 50 \%$, or $75 \%$. Because there is no valid estimation/prediction of remittance inflow during this time. One method would be taking the proportion ate percentage of the labor returning to the home country among total labor supplied. However, there is not sure that the labor, who are still living in foreign countries, are actively earners. Therefore, the assumption of loss in remittance/GDP is a quiterelevant idea.

In the second step, the economic growth rate-remittance/GDP linear relationship explores a fixed coefficient between them. Hence, we can predict the economic growth of Nepal in the reverse direction, when the remittance/GDP scrutinizes by $25 \%, 50 \%$, or $75 \%$. During the estimation, other control explanatory variables are kept constant. Finally, it reshapes 
the possible slowdown of the GDP growth rate for FY 2020. During the study, the time series sample (forecast sample)is chosen from FY 2000 to 2019. Trend forecasts are based on the polynomial equation of order 2 . The transmission approach is looking as like follows:

$$
\text { COVID }-19 \uparrow \rightarrow \text { Remitance Inflow } \downarrow \rightarrow \text { Economic Growth Rate } \downarrow
$$

Now, the ordinary least square regression model is specified as follows:

$\log (\mathrm{RGDP})_{\mathrm{t}}=$ Constant $+X_{t} \varsigma^{\prime}+\varepsilon_{t}$,

Where,

$\log ($ RGDP $)=\log$ of the real gross domestic product,

$\mathrm{X}_{\mathrm{t}}=$ set of explanatory variables: REM/GDP, GFEX/GDP, GCF/GDP, and INF.

$\mathrm{REM} / \mathrm{GDP}=$ remittance to GDP ratio,

GFEX/GDP = government final expenditure to GDP ratio,

GCF/GDP = gross capital formation as a percentage of GDP,

$\mathrm{INF}=$ inflation rate,

$\varsigma^{\prime}=$ coefficient vector of each explanatory variable, and

$\varepsilon_{t}=$ error term.

$\mathrm{t}=2000, \ldots, 2010$ (base year),..., 2019.

Note: All the variables are sourced from the World Bank.

\section{RESULT AND DISCUSSION}

The present study confirmed the few notable findings underexplained research methods.Figure 1lucidly demonstrates the possible size of remittance to GDP ratio for FY 2020 in case of a large increment of coronavirus pandemic. The share of remittance in GDP would be about $27.95 \%$ in normal economic conditions for FY 2020, where it was only $25.38 \%$ in the previous year. But,due to COVID-19, the forecasted value for FY 2020 must deviate from its normal projection. It is also observed that the share of remittance in GDP will be downsized up to $21 \%, 14 \%$, or $7 \%$ respectively, in case of declining its size by $25 \%, 50 \%$, or $75 \%$ respectively for FY 2020. 
Figure 1: Plausible retardation in remittance/GDP size due to COVID-19 in Nepal for 2020

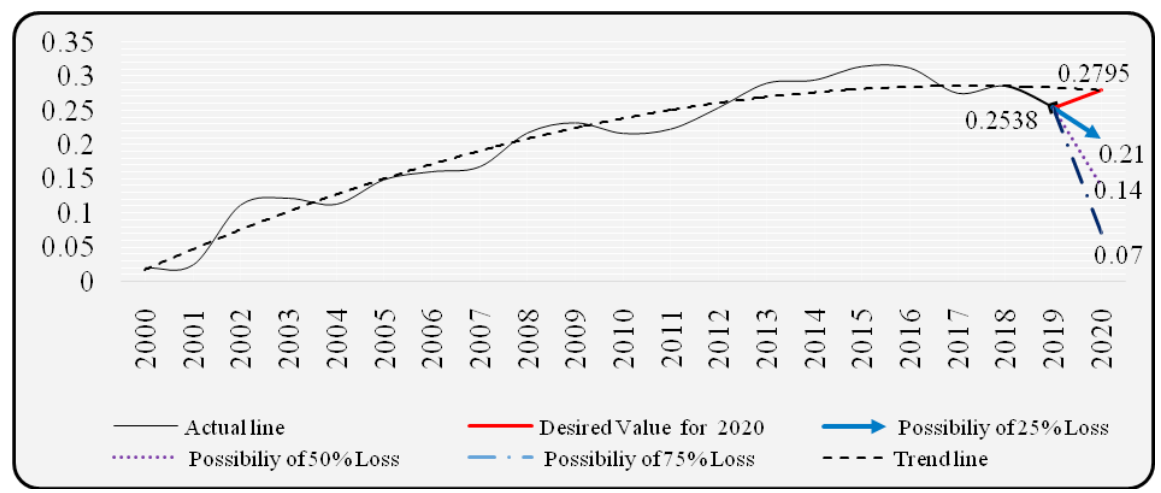

Source: Author's estimation

Furthermore, the estimated model Table 1 reveals that the economic growth rate of Nepal significantly augments by $0.010984 \%$ per annum in per unit increment of remittance's share in GDP. The finding is similar to the Javid, Arif, and Qayyum (2012); Katsushi et al. (2012); Srivastava and Chaudhary (2007).Furthermore, among the control variables (GFEX/ GDP, GCF/GDP, INF), gross capital formation to GDP (GCF/GDP) reacts positively to the economic growth rate.

Table 1: Estimated result of the model

\begin{tabular}{lc}
\hline & Dependent Variable: $\log (\mathrm{RGDP})$ \\
\hline Explanatory Variables & Coefficient \\
REM/GDP & $0.010984 * * *$ \\
GFEX/GDP & 0.010021 \\
GCF/GDP & $0.002708^{* *}$ \\
INF & 0.002187 \\
Constant & $22.92 * * *$ \\
\hline & $\mathrm{R}^{2}=0.99125$ \\
& Adjusted $\mathrm{R}^{2}=0.98874$ \\
& $D-W$ Statistic $=2.26$ \\
& F-statistic $=396.677(\mathrm{P}-\mathrm{value}=0.0000)$ \\
$\chi^{2}$ Normality $\mathrm{J}^{\mathrm{B}}=0.7833(0.6759)$ \\
$\chi^{2}$ Heteroskedasticity $=6.54(0.166)$ \\
$\chi^{2}$ Serial Correlation LM Test $=0.8422(0.3587)$ \\
\hline
\end{tabular}

Source: Author's estimation 
The result of diagnostic tests of the model shows that the estimated model is free from serial correlation and other tests are overall good. Based on these findings, furthermore, it predicts the conceivable loss in economic growth rates based on given assumption or possibility of retardationin remittance to GDP share in the coming time. In the same token,Figure 2 illustrates the growth rate will be down scaled from 0.2746 to $0.8238 \%$ if remittance to GDP ratio plummets from $25 \%$ to $75 \%$ respectively for FY 2020 .

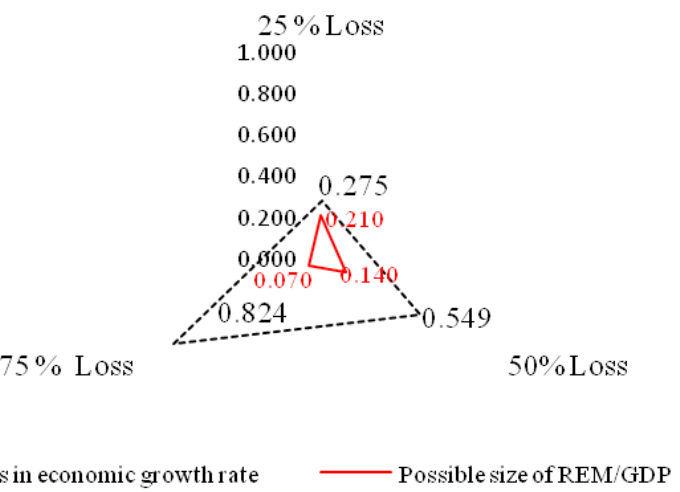

Figure 2: Possible size of REM/GDP and economic growth rate reduction for FY 2020

Source: Author's estimation

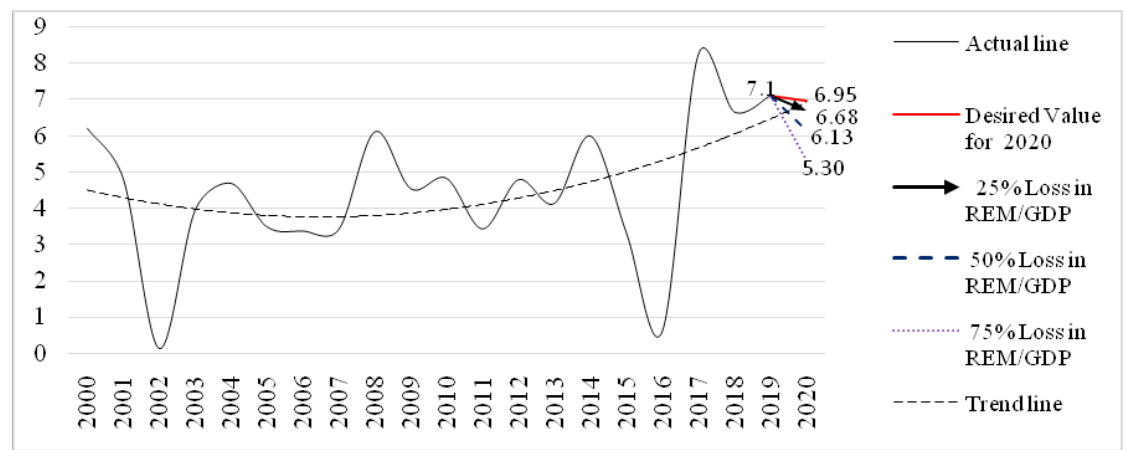

Figure 3:The possible rate of economic growth of Nepal for FY 2020

Source: Author's estimation 
Table 2: Total transmission effect

\begin{tabular}{|c|c|c|c|c|c|}
\hline & \multicolumn{2}{|c|}{ Normal condition } & \multicolumn{3}{|c|}{ COVID-19 regime $\left(2020^{*}\right)$} \\
\hline & 2019 & $2020^{*}$ & $\begin{array}{l}25 \% \text { loss in } \\
R E M / G D P\end{array}$ & $\begin{array}{l}50 \% \text { loss } \\
\text { inREM/GDP }\end{array}$ & $\begin{array}{l}75 \% \text { loss in } \\
R E M / G D P\end{array}$ \\
\hline $\begin{array}{l}\text { Remittance/ } \\
\text { GDP }\end{array}$ & 25.38 & 27.95 & 20.96 & 13.98 & 6.99 \\
\hline $\begin{array}{l}\text { Economic } \\
\text { Growth }\end{array}$ & 7.1 & 6.95 & 6.68 & 6.13 & 5.3 \\
\hline
\end{tabular}

Note: * is the forecasted value

Source: World Bank, and Figures: $2 \& 4$.

Finally Figure 3 reveals the final result of the raised issues of the paper, and Table 2 is the summary of all transmission effects. In a normal situation (absence of COVID-19), the remittance/GDP and economic growth rate would be $27.95 \%$ and $6.95 \%$ for 2020 . Where it was recorded 25.38 $\%$ and 7.1 respectively in the previous year 2019. The forecasts have 2.008 and 1.755 RMSE values respectively. It shows that the forecasted values are desirable. Due to the uncertainty movement of the virus, remittance definitely will retard for 2020. The study forecasts that if remittance/GDP size is reduced by $25 \%$, it leads to contrast the economic growth rate up to $6.68 \%$ keeping other things constant. When the situation becomes worse, remittance/GDP size will be more fragile. In the case of $75 \%$ reduction in remittance/GDP share, it will scrutinize the economic growth rate up to 5.3 $\%$. Regarding this, the Asian Development Bank (2020a) has forecasted that the GDP growth rate of Nepal likely moderate to $5.3 \%$ in FY 2020, down from $7.1 \%$ a year earlier.

\section{CONCLUSION}

The increasing coronavirus pandemic has established immediate health and economic emergency across the globe. Most of the economies have been suffering from it. The economy like Nepal, which is based on remittance, is mostly affected now. The role of remittance in Nepal is so immense on the micro as well as macro-level. The paper aims to investigate the possible loss in GDP growth rate for FY 2020 due to possible retardation in remittance inflow (\% of GDP) under the explosion of the COVID-19. The study has utilized transmission mechanism to address the issue with proper use of trend forecast,and ordinary least square method. The time series sample (forecast sample) of the study is FY 2000 to 2019. The paper concludes that decreasing remittance significantly hampers the growth 
rate of Nepal. If the pandemic proliferates more, and if it down sizes the remittance/GDP by $25 \%$ to $75 \%$, and it retards the projected GDP growth rate (6.95)up to 6.68 to $5.3 \%$ for FY 2020. The picture depicts that the national resource gap may be going on wider and wider during the pandemic time. Basic consumption cannot be reduced, which also demonstrates the possibility of narrow domestic saving in the coming time. In this situation, the government of Nepal should stand on investing in alternatives sectors, for instance in rural agriculture, animal husbandry, fisheries,construction, and so on. This is a better alternative of income generation for return ingmigrant youths and other unemployed masses of the country.

\section{ACKNOWLEDGMENTS}

I would like to acknowledge Prof. Kushum Shakya (Dean, Faculty of Humanities and Social Sciences, Tribhuvan University), Asst. Prof. Naveen Adhikari (Faculty member of Central Department of Economics, Tribhuvan University), and the anonymous referees for their valuable comments and suggestions.

\section{REFERENCES}

Asian Development Bank. (2020a). An updated assessment of the economic impact of COVID-19: Asian Development Bank Briefs No. 133. https://www.adb.org/sites/default/files/publication/604206/adbbrief-133-updated-economic-impact-covid-19.pdf

Asian Development Bank. (2020b). Macro-economic updates: Nepal, Vol 8 No 2. https://aus.libguides.com/c.php?g=299652\&p=2001146

Bhandari, R. M. (2018). Contribution of remittance to promote women empowerment in Nepal: A case study of Kirtipur Municipality (Unpublished master's thesis): Central Department of Economics, Tribhuvan University, Kathmandu.

Calaro, C. (2008). Remittances, liquidity constraints, and human capital investment in Ecuador. World Development, 37(6): 1143-1154.

CBS. (2011). Nepal living standards survey - III, 2010/11. Kathmandu: Central Bureau of Statistics.

Chai, T. (2014). Root mean square error (RMSE) or mean absolute error (MAE)?-Arguments against avoiding RMSE in the literature. Geoscientific Model Development, 7(3):1247-1250. 
Chami, R., Fullenkamp, C. \& Jahjah, S. (2003). Are immigrant remittances flows a source of capital for development? IMF Working Paper WP/03/189. https://www.imf.org/en/Publications/WP/ Issues/2016/12/30/Are-Immigrant-Remittance-Flows-a-Sourceof-Capital-for-Development-16801

Dhungana, B. R. (2014). Remittance and Nepalese economy. Journal of $S M C, \mathbf{5 : 1 - 1 5 .}$

Gaudel, Y. S. (2006). Remittance income in Nepal: Need for economic development. The Journal of Nepalese Business Studies, 3(1): 9-17.

Gautam, D. (2017). Socio-economic contribution of remittance in Nepal: A case study of Birendranagar municipality (Unpublished master's thesis). Central Department of Economics, Tribhuvan University, Kathmandu.

IATA. (2020). International traveldocumentnotes. International Air Transport Association Coronavirus Update. https://www.iatatravelcentre. com/international-travel-documentnews/1580226297.htm

ILO. (2020). COVID-19 and the world of work: Impact and policy responses. Switzerland: International Labour Organization.

IMF (2009). Balance of payments and international investment position manual (BPM6). Washington D.C: International Monetary Fund.

Javid, M., Arif, U. \& Qayyum, A. (2012). Impact of remittances on economic growth and poverty. Academic Research International, 2(1): 433-447.

John, B. E., Lawal, M. T., Yaw, O., Junior, O. D. \& Mahesh, M. (2015). Remittance and economic growth: Evidence from West Africa. International Journal of Multidisciplinary Studies, 5(5):73-83.

Karagoz, K. (2009).Workers' remittances and economic growth: Evidence from Turkey. Journal of Yasar University, 4(13): 1891-1908.

Karagoz, M. (2009). Reveals that remittance flow has a statistically meaningful but negative impact on growth in Turkey.International Journal of Academic Research in Business and Social Sciences, 15(5): 12-27.

Klimburg, A., Faesen, L., Verhagen, P. \& Philipp, M. (2020). COVID-19, information technology, and cognitive dissonance. Netherlands: Hague Centre for Strategic Studies. 
Klonowska, K. (2020). The COVID-19 pandemic: Two waves of technological responses in the European Union. Netherland:Hague Centre for Strategic Studies.

Krugman, R.P.,Obstfeld, M. \& Melitz, M.J.(2012). Internationaleconomics: Theory and policy. United States: Addison-Wesley.

Maliszewska, M., Matto, A. \& Mensbrugghbe, D.V.D. (2020). The potential impact of COVID-19 on GDP and trade. World Bank Group Policy Research Working Paper No.9211. https://openknowledge. worldbank.org/handle/10986/33605

Pant, B. (2011). Harnessing remittances for productive use in Nepal. Economic Review, 23: 1-20.

Shrestha, B. (2008). Contribution of foreign employment and remittances to the Nepalese economy. Economic Review, 20: 1-15.

Sophie, I. (2019). The world's top recipient of remittance, 2018. CEOWORLD Magazine. https://ceoworld.biz/2019/06/10/remittance-inflows/

Srivastava, N. L. \& Chaudhary, S. K. (2007). Role of remittance in the economic development of Nepal. The Journal of Nepalese Business Studies, 4(1): 28-37.

World Health Organization. (2020). WHO Interact. https://covid19.who. int/. (Assessed: 11.07.2020) 